\title{
Critical Reading Strategies in Language Learning: an Overview of Leading Approaches
}

\author{
Zinaida Vozgova \\ Department of Foreign Languages with Latin Course \\ South Ural State Medical University \\ Vorovskogo Street, 64, 454092 Chelyabinsk \\ Russian Federation \\ e-mail: zinaidavozgova@mail.ru \\ Olga Afanasyeva \\ Faculty of English Philology \\ South Ural State Humanitarian Pedagogical University \\ Lenin prospect, 69, 454080 Chelyabinsk \\ Russian Federation \\ e-mail: afanasevaou@cspu.ru
}

\begin{abstract}
Fast changes in core skills required to perform a job include analytical thinking and active learning. Thus, 'human' skills such as critical thinking, persuasion and negotiation increase their value and require attention to detail, flexibility and complex problem-solving.

Our study presents texts as social acts and critical reading strategies as analytic pedagogic procedures in language learning. Based on critical discourse analysis and its three-dimensional framework the article aims at presenting critical reading activities as well as corresponding skill characteristics in accordance with the four-stage procedure (pre-reading speaking, while-reading and interpreting, follow-up writing and critical expansion tasks).

Our contribution provides an overview of the leading approaches in providing a critical classroom community with the necessary tools to engage in complex discussion of the meaning of social texts and point out instances of socio-cultural practices (power manipulation, exploitation, gender inequalities, etc).
\end{abstract}

\section{Introduction}

The issue of critical reading traditionally seems omnipresent and refers to an increasing international academic movement of " $21^{\text {st }}$ century skills" for students' success in a fast-moving digital world. The Internet provides great opportunities for a diverse online analytic course such as "Mindware: Critical Thinking for the Information Age", "Creative Problem Solving", "Critical Thinking and Persuasive Writing”, etc. Core academic knowledge remains crucial but successful students have to collaborate, innovate, adapt, be self-directed, be flexible, be creative, be tech-literate, practice teamwork and be accountable. Analytic reasoning, critical thinking, complex problem solving, creativity and innovation, communication and collaboration are associated with deeper learning and are not primarily based on rotelearning or mindless memorizing facts or ideas. Not only should students be collaborative and accountable to innovation, but they should also be "open to other people's ideas and opinions". It is important to engage with people who disagree so that a solution that the entire group agrees can be found.

Nowadays readers are no longer just observers; they are participators and interpreters as they are involved in complex discussion of the meaning of social texts (Habermas and Nielsen 1990). It is the interpretive communities, not the text or the reader, that form the meanings. Learners need to explore the materials and procedures which promote critical reading, embrace not only an approach to specific texts but eventually ways of relating those readings to wider social practices. Thus, modern interactive textbooks (Goatly 2013; Caplan and Douglas 2011) go on exploring socially relevant phenomena behind the texts learners might encounter in their everyday life (in popular fiction, advertisements, print newspapers, blogs, etc) as well as examining the language choices a writer makes in structuring texts, representing the world or positioning a reader. The term "critical classroom community" is becoming more relevant as critically minded learners are aware of social injustice problems in the modern world. During the critical analysis of the text they can point out instances of socio-cultural practices (power manipulation, exploitation, gender inequalities, xenophobia, ethnocentrism, racism, etc). 


\section{Critical discourse analysis}

Social nature of discourse is unquestionable as there is no such thing as a 'non-cultural' or 'non-historical' use of discourse (Blommaert, 2005). We all use discourse to render meaningful aspects of social, cultural, political environment. As discourse transforms our environment into a socially and culturally meaningful one, critical analysis of discourse in contemporary society presents an analysis of voice (Voloshinov, Bakhtin, Ducrot, or Hymes). Critical discourse analysis (CDA) presents an interdisciplinary approach and is aimed to view spoken/ written language as a form of social practice. CDA focuses on the ways discourse structures enact, confirm, legitimate, reproduce, challenge relations of power or dominance in society. Fairclough (2001) introduced crucial concepts of discourse, power, ideology, social practice and common sense. Wodak (1999) devised an interdisciplinary problem-oriented 'discourse historical' paradigm to analise changes of critical discourse practices, rules, mechanisms that can explain how the meaning is negotiated between members of a discourse community over time in various genres. Van Dijk (2006) introduced principles of critical discourse analysis with the focus on dominance relations by elite groups and institutions as they are being enacted, legitimated or otherwise reproduced by text and talk.

Initiated with Critical Linguistics (Fowler, Hodge, Kress \& Trew, etc) CDA with its focus on language and discourse is aimed to examine the ideological coding of texts. With the help of specifically devised text-analytic procedures by renowned critical discourse analysts (Fairclough 2001; Kress 1996) critical linguistics illuminates a whole range of associated phenomena, topics and relations of the discourses embedded within texts.

Furthermore, taking into consideration the main tenets of CDA (Fairclough and Wodak) it is crucial to point out that discourse as a form of social action is interpretative and explanatory. Based on history, discourse constitutes society and culture and provides the link between texts and community. Interpreting real-world socio-cultural problems, discourse does ideological work. By exploring and interpreting patterns of language choices, one can uncover the ideological leanings of ambivalent and contradictory texts, scrutinize the manner of writing (or the voice) and analyze privilege of certain social groups over others. Some researchers (Blommaert and Verschueren 2002) examine the most vital issue facing the world today - the politics of difference (racism, ethnicism, immigration, nationalism).

What is more, CDA is committed to social change. Critical discourse analysts examine all types of semiotic material (written texts, interviews and talk shows, radio and television programmes, print or online newspapers and magazines, blogs and podcasts, social networking sites and advertisements) to show how language figures within relations of power, manipulation, inequality, etc. In order to apply critical reading and thus interpret power and discourse in an explicit way, we need to be equipped with 'cognitive interface' (Van Dijk, 2001) of various models of social representations which relate the individual and the social, the micro- and the macro-levels of community structure.

\section{Critical Reading}

Critical reading (as well as critical thinking) presents an integral part of the notion of classroom as critical community. It contributes to a learner's 'critical language awareness' to be able to analyse texts through the lens of discourse and requires careful pre-planning as well as a wide range of efficient methodologies integrated into curriculum. It is important to note that all spoken or written texts are by-products of social interaction, thus from the discursive perspective it is crucial to teach language learners to interpret texts as social acts. Students should be able to explore and interpret the real-world settings and socially relevant issues behind the texts they encounter in their everyday lives (via the Internet, print media, radio or TV programmes, podcasts, mail, social networking sites, etc).

Critical reading strategies imply knowledge of Critical Linguistics, Critical discourse analysis, media and political discourse, etc. Therefore, teaching critical reading strategies is a complex task; it remains the matter of thorough international research of leading psychologists, pedagogues, methodologists, analysts, etc.

Pennycook (2001) introduced a comprehensive account of Critical applied linguistics; Canagarajah (2002) implemented critical principles in teaching EFL; Halpern (2014) applied cognitive psychology theories to the development of critical thinking and learning skills (i.e. determining cause, assessing likelihood and uncertainty, comprehending complex text, solving novel problems, making good decisions, evaluating claims and evidence, thinking creatively).

Ennis (2015) developed his notion of critical thinking, its assessment and teaching in the classroom. He believes that critical thinking skills can be acquired independently, outside of a specific scientific discipline. They are universal, that is, they can be applied in various fields of knowledge. An outline of critical thinking dispositions and abilities can be summarized as following: 
1. Learners should aspire to get all the required information accurately so that their beliefs could be true and relevant, which also implies:

- to be open-minded to alternative hypotheses and explanations;

- to be well-aware and well-informed;

- to take into consideration different perspectives or views;

- $\quad$ to be able to develop your learning skills and broaden your outlook

2. Learners should spell out clearly and carefully their own and other people's points of view:

- to be able to understand the meaning of oral and written texts as accurately and effectively as the situation requires, that is:

- $\quad$ to be able to concentrate on the issue and focus on the findings;

- to come up with well-reasoned justification;

- to take into consideration a situation entirely;

- to become aware of your own convictions.

3. Learners should respect other people's dignity and point of view:

- to be able to heed your interlocutor's point of view and arguments, that is:

- to take into account other people's level of knowledge, to be considerate to an interlocutor's feelings and stay away from any critical remarks and conflicts.

Therefore, critical reading skills can be developed around real-world thought-provoking situations or case-studies when students interpret and assess new material. Critical principles in language learning and teaching EFL (Canagarajah 2002) centred on reading activities help teachers lead students through social issues to achieve specific learning outcomes.

In order to single out separate forms of critical discourse analysis it is important to develop a framework for an exploration of classroom-based critical reading. Based on the functional grammar (Halliday 1994) one can derive the following three perspectives on the meanings encoded within a social context - textual, conceptual and interpersonal. Eggins (1994) uses a similar structure for modelling linguistic choices, a concept which underlies Halliday's Grammar as well. Fairclough (2001) takes the same perspective on social discourse and derives its underlying theoretical linguistic framework to outline three forms of analysis onto one another (see Table 1).

Table 1. Three-dimensional framework for critical reading analysis

\begin{tabular}{|c|c|c|}
\hline $\begin{array}{c}\text { Levels of } \\
\text { discourse } \\
\text { interpretation }\end{array}$ & $\begin{array}{l}\text { Perspectives of } \\
\text { text meaning }\end{array}$ & Characteristics of critical discourse analysis \\
\hline $\begin{array}{l}\text { micro-level } \\
\text { (level of } \\
\text { linguistic } \\
\text { practice) }\end{array}$ & textual meaning & $\begin{array}{l}\text { Analysis of (spoken and written) language texts (e.g. } \\
\text { syntactic analysis, use of literary tropes (metaphors, } \\
\text { hyperbole, metonymy, etc), rhetorical devices; ways } \\
\text { in which texts are organized (headlines, sentences, } \\
\text { paragraphs, genre structures) }\end{array}$ \\
\hline $\begin{array}{l}\text { meso-level } \\
\text { (level of } \\
\text { discourse } \\
\text { practice) }\end{array}$ & $\begin{array}{l}\text { conceptual } \\
\text { meaning }\end{array}$ & $\begin{array}{l}\text { Analysis of text production, distribution and } \\
\text { consumption (e.g. which institution/organization } \\
\text { produced a text, who is the target audience, etc) }\end{array}$ \\
\hline $\begin{array}{l}\text { macro-level } \\
\text { (level of } \\
\text { interdiscursive } \\
\text { practice) }\end{array}$ & $\begin{array}{l}\text { interpersonal } \\
\text { meaning }\end{array}$ & $\begin{array}{l}\text { Analysis of real-world settings and socially relevant } \\
\text { phenomena that are affecting the text being studied } \\
\text { (instances of socio-cultural practices: power } \\
\text { asymmetries, manipulation, exploitation, inequalities, } \\
\text { ethnocentrism and racism, etc) }\end{array}$ \\
\hline
\end{tabular}

Source: own results

\section{Critical Reading activities}

Based on critical discourse analysis Wallace (2006) came up with the critical reading course which included the following recommendations: 
1. Students should be interested in discussion. They should be aware of what is happening in the world and show interest in current situation in society.

2. Some texts may seem overloaded with specific cultural characteristics. Therefore, it is recommended to start critical analysis with texts of familiar genres and written in a clear language.

3. The plan of each lesson should include an extended pre-text stage. It is important to elicit previously known facts, opinions, historic, socio-cultural references in order to make up a plan, draw up a scheme or fill in a table. After a brainstorming session it is recommended to proceed to a more detailed analysis of the given text in small groups.

Linguists, discourse analysts as well as educators have acknowledged the importance of critical reading and critical literacy (Cervetti et al. 2001). Critical reading is feasible and applicable as an analytic pedagogic procedure. It is important to point readers' attention to discourse features as most texts are ideologically permeated. Within classroom environment 'critical community' is aimed to help language learners apply critical reading skills needed to scrutinize texts, analyse arguments, reason clearly, identify and interpret socio-cultural issues.

Critical reading and interpretation do not present language and textual facts as mere objects of mechanical activity, but they involve 'dynamic interaction between reader and text' of which meaning is the 'product' (Fish 1984). The study of language as a socio-cultural phenomenon introduces the main category of the so-called "interpretive community" as readers or like-minded people interpret text in a certain way and form a certain point of view. Fish believes that neither a text nor a reader can have an independent status. The text arises as a result of the consistent application of interpretative practices and models. Interpretative strategies include a form of the reading, they give text certain form but do not arise from it. These strategies are developed by the community of which reader is a member. In reality this property of interpretive community makes it possible at the same limit mind activity as reader acts as part of the community. It is the interpretive communities, not text or readers, that form the meanings (Fish 1984).

Classroom-based critical reading can be designed as an optional course/module or can be integrated into language classes with the help of specific interactive tasks or textbooks (Caplan \& Douglas 2011). Thus, the undergraduate students at South Ural State Humanitarian Pedagogical University (Chelyabinsk, Russian Federation) in their third, fourth and fifth year of study tested critical reading tasks in the EFL courses and found 'critical language awareness' classes efficient and productive as they expanded on language learners' critical thinking and problem solving skills, thus preparing to excel in their further career. The notion of classroom as critical community appealed a great deal to the students as they were engrossed in the ideology behind the text by scrutinizing and interpreting various socio-cultural phenomena.

Critical reading course is based on Critical thinking approach and implies both new socio-cultural information processing and its application to a new situation. Critical Reading classes centres on texts as social acts. The course materials, speaking and writing follow-up tasks as well as critical expansion activities (team, pair and individual) add up to a general collaborative interaction between teacher and students, or student and student. Nowadays students need to apply critical reading skills they have acquired to new situations with materials they have never seen before. In this respect critical expansion activities increase critical thinking approach and facilitate more practice for language learners. As questions are important catalysts in critical reading environment students learn to analyse, synthesize, evaluate and interpret thought-provoking issues decoding textual, conceptual and interpersonal meanings.

Reading activities in methodology traditionally involve three stages: pre-reading, while-reading and post-reading. In this regard critical reading class encompasses pre-reading speaking activities, whilereading and interpreting, follow-up writing and critical expansion activities (Caplan \& Douglas, 2011). In the table below we present a variety of critical reading activities as well as corresponding skill characteristics in accordance with the above mentioned four-stage procedure (see Table 2 that follows).

Back in the 1970s, in 'Pedagogy of the Oppressed' Freire (1970) criticized the so-called 'banking conception of education' and revealed the concept of communication as sharing meanings about realities through critical dialogue. Analytic reasoning via discussions, debates, exchange of arguments is crucial at this stage. When developing students' critical reading skills, a teacher acts as a moderator or facilitator. He does not seek to single-handedly create 'interpretive community' in a classroom environment or install students with a definite point of view on a given socio-cultural issue. On the contrary, a teacher acts as an intermediary and an assistant, whereas students (in small group, pairs or individually) are given the opportunity to freely express their points of view.

The term 'critical group' or 'critical classroom community' implies that critically minded members are aware of the problems of social (in)justice in the modern world. During critical analysis of texts, they point out the unequal attitude of the author, analyse the target audience and interpret various 
instances of socio-cultural practices: power asymmetries, manipulation, exploitation, inequalities, ethnocentrism, racism, etc.

Table 2. Types of critical reading activities

\begin{tabular}{|c|c|c|}
\hline Stages & Types of activity & Learning outcomes \\
\hline $\begin{array}{l}\text { Pre-reading speaking } \\
\text { activities }\end{array}$ & $\begin{array}{l}\text { Brainstorming } \\
\text { Previewing reading } \\
\text { Opinion surveys } \\
\text { Role-play }\end{array}$ & $\begin{array}{l}\text { As students brainstorm ideas, they synthesize new } \\
\text { information, come up with a plan/strategy, develop } \\
\text { new skills } \\
\text { To get tech-literacy skills students are exposed to a } \\
\text { huge amount of information and learn to question, } \\
\text { analyse and critically evaluate where this information } \\
\text { is coming from } \\
\text { To communicate opinions clearly students, learn to } \\
\text { choose relevant correct collocations. At the same time } \\
\text { role-play activities teach students to be specific and } \\
\text { polite when disagreeing or distancing from the idea }\end{array}$ \\
\hline $\begin{array}{l}\text { While- Reading } \\
\text { And Interpreting }\end{array}$ & $\begin{array}{l}\text { Distinguishing main } \\
\text { ideas from details } \\
\text { Identifying } \\
\text { contrasting ideas } \\
\text { Previewing a text } \\
\text { Making inferences } \\
\text { Following ideas } \\
\text { Annotating a text }\end{array}$ & $\begin{array}{l}\text { Students learn to decode within a given social context } \\
\text { textual, conceptual and interpersonal meanings. } \\
\text { The ability to identify an author's intent and } \\
\text { understand narrative structure as essential parts of } \\
\text { critical literacy help students examine and interpret } \\
\text { various socio-cultural issues, decide if information is } \\
\text { suitable for a particular need. } \\
\text { As life inside and outside of work is becoming } \\
\text { increasingly influenced by globalization, students } \\
\text { learn to develop cross-cultural awareness by analysing } \\
\text { the reasons for success in different countries } \\
\text { They learn to anticipate content through thought- } \\
\text { provoking questions; organize their notes and } \\
\text { annotations in T-chart; reorganize information in } \\
\text { Venn diagram, }\end{array}$ \\
\hline $\begin{array}{l}\text { Follow-up } \\
\text { activities }\end{array}$ & $\begin{array}{l}\text { Process essay } \\
\text { Persuasive essay } \\
\text { Analytical essay } \\
\text { Cause-and-Effect } \\
\text { Essay } \\
\text { Proposal } \\
\text { Speech } \\
\text { Extended definition } \\
\text { Summary }\end{array}$ & $\begin{array}{l}\text { Writing is a common requirement in many fields of } \\
\text { work. Students learn research the type and format of } \\
\text { writing genres in the intended careers. They learn to } \\
\text { combine a basic skill (description) with other high- } \\
\text { order skills (evaluation, recommendation, } \\
\text { interpretation, persuasion, etc). } \\
\text { By eliciting real-life situations in which problems } \\
\text { need to be described, evaluated and solved, students } \\
\text { learn to use evidence and provide solid facts to } \\
\text { support their opinions, ideas and arguments. }\end{array}$ \\
\hline $\begin{array}{ll}\text { Critical } & \text { expansion } \\
\text { activities } & \end{array}$ & $\begin{array}{l}\text { Outlining } \\
\text { Generalization } \\
\text { Paraphrasing } \\
\text { Transference }\end{array}$ & $\begin{array}{l}\text { These activities facilitate more practice and expand on } \\
\text { critical thinking skills } \\
\text { Students apply the skills they have learned to new } \\
\text { situations with materials they have never seen before }\end{array}$ \\
\hline
\end{tabular}

Source: Own results

Furthermore, it is important to emphasize empathy as a key factor because students learn to put themselves in the place of others and try to understand why another interlocutor might consider this or that act to be fair or not. To develop language learners' critical reading skills teacher constantly interacts with students. This collaboration encompasses three phases: challenge (awakening interest in the subject), meaning realization (material comprehension while working on it) and reflection (summarizing the material).

\section{Conclusions}

Our findings on leading critical reading strategies with its corresponding activities and learning outcomes allow drawing the following conclusions. Global shift in required workplace skills such as creativity, originality and initiative, emotional intelligence and critical thinking is set to see further particular increase 
in demand relative to their current prominence today. Reading in a critical class community involves complex collaborative interpretation and discussion of the meaning of social texts.

Critical discourse analysis presents an interdisciplinary approach to view spoken/written language as a form of social practice and is aimed to examine the ideological coding of texts. By exploring and interpreting patterns of language choices students uncover ideological leanings of ambivalent and contradictory texts, scrutinize the manner of the voice and analyse privilege of certain social groups over the others. Critical reading contributes to a learner's 'critical language awareness' as well as a wide range of efficient methodological activities integrated into curriculum. Based on three-dimensional framework (micro-, meso- and macro-level) for critical reading analysis perspectives of texts include textual, conceptual and interpersonal meanings.

Critical reading can be applied as an analytic pedagogic procedure, which enables language learners' skills needed to scrutinize texts, analyse arguments, reason clearly, identify and interpret sociocultural issues. Classroom-based critical reading activities facilitate more dynamic interaction between a reader and a text. Implementation of critical thinking activities encompass pre-reading speaking, whilereading and interpreting, follow-up writing and critical expansion tasks.

\section{References}

Angermuller J, Maingueneau D, Wodak R (eds). The discourse studies reader: Main currents in theory and analysis, $1^{\text {st }}$ edn. (John Benjamins Publishing Company, NY, 2014), 416 p.

Blommaert J. Discourse: A critical introduction, 1st edn. (Cambridge University Press, 2005), 299 p.

Blommaert J. Verschueren J. Debating diversity: Analysing the discourse of tolerance, $1^{\text {st }}$ edn. (Routledge, London, 2002), 247 p.

Brown G, Gillian B, \& Yule G. Discourse analysis, $1^{\text {st }}$ edn. (Cambridge University Press, Cambridge, 1983), $288 \mathrm{p}$.

Caplan NA, Douglas SR, Q: Skills for success: Reading and writing, $1^{\text {st }}$ edn. (Oxford University Press, Oxford, 2011), $277 \mathrm{p}$.

Cervetti G, Pardales MJ and Damico JS (2001) A Tale of Differences: Comparing the Traditions, Perspectives, and Educational Goals of Critical Reading and Critical Literacy. www.readingonline.org/articles/cervetti. Accessed on 15 November 2019

Eggins S. An Introduction to Systemic Functional Linguistics, $1^{\text {st }}$ edn. (London: Pinter Publishers, 1994), $360 \mathrm{p}$.

Ennis RH Critical Thinking: A Streamlined Conception. In: Davies M., Barnett R. (eds) The Palgrave Handbook of Critical Thinking in Higher Education, $1^{\text {st }}$ edn. (New York: Palgrave Macmillan, 2015), 230 p.

Fairclough N Language and Power. $2^{\text {nd }}$ edn. (Harlow: Pearson Education Limited, 2001), 227 p.

Fish S (1984). Fish v. Fiss. Stanford Law Review 36(6):1325-1347. doi:10.2307/1228671

Fowler R. Language in the News: Discourse and Ideology in the Press, $1^{\text {st }}$ edn. (London: Routledge, 1991), $254 \mathrm{p}$.

Goatly A. Critical reading and writing: An introductory coursebook, $1^{\text {st }}$ edn. (London: Routledge, 2013), 364 p.

Habermas J, Nielsen T, Habermas (1990) Society and Ethics - an Interview with Nielsen, Torben, HVIID, pp. 93-114.

Halliday M An Introduction to Functional Grammar, $2^{\text {nd }}$ edn (London, Routledge, 1994), 432 p.

Halpern D Critical thinking across the curriculum: A brief edition of thought $\&$ knowledge, $1^{\text {st }}$ edn. (New York: Routledge, 2014), 296 p.

Kress G, Linguistic Processes in Sociocultural Practice, $1^{\text {st }}$ edn. (Oxford University Press, Oxford, 1989), $101 \mathrm{p}$.

Leonard P, McLaren P, (eds.) Paulo Freire: A critical encounter, $1^{\text {st }}$ edn. (Routledge, 2002), 194 p. 
Trew T What the papers say: linguistic variation and ideological difference. Language and control, $1^{\text {st }}$ edn. (Routledge, London, 2018), 156 p.

Van Dijk TA (1993) Principles of critical discourse analysis. Discourse \& Society 4(2):249-283. doi: $10.1177 / 0957926593004002006$

Van Dijk TA Critical discourse analysis. In D. Tannen, D. Schiffrin, \& H. Hamilton (eds.), Handbook of discourse analysis, $1^{\text {st }}$ edn. (Oxford: Blackwell, 2001), pp. 352-371.

Wallace C Critical reading in language education, $1^{\text {st }}$ edn. (Palgrave Macmillan, New York, 2006), 217 p.

Wodak R (1999) Critical discourse analysis at the end of the $20^{\text {th }}$ century. Research on Language \& Social Interaction 32(1-2):185-193. doi: 10.1207/S15327973RLSI321\&2_22 